\title{
Long-term creatine supplementation improves the aerobic capacity of horses
}

\author{
Suplementação prolongada com creatina melhora a capacidade aeróbica de eqüinos
}

\author{
Guilherme de Camargo Ferraz $^{1}$ Antônio Raphael Teixeira-Neto ${ }^{1}$ \\ Flora Helena de Freitas D’Angelis ${ }^{1}$ José Corrêa de Lacerda-Neto ${ }^{2}$ \\ Antonio de Queiroz-Neto ${ }^{3}$
}

\begin{abstract}
The aim of the present study was to investigate the effect of long-term oral supplementation of creatine on the physiological responses to aerobic training. Twelve purebred Arabian horses were submitted to aerobic training for 90 days, with and without creatine supplementation which consisted of the daily administration of $75 \mathrm{~g}$ of creatine monohydrate mixed into the ration for 90 days of training. Physical conditioning was conducted on a high performance treadmill and training intensity was stipulated by calculating the $V_{4}$ (velocity at which blood lactate reaches $4 \mathrm{mmol} \mathrm{L}^{-1}$ ) determined monthly for each animal. The individual intensity of physical force at $80 \%$ of aerobic threshold was established. An incremental exercise test was used to set the individual V4. After a warm up period of 4 min at $4 \mathrm{~m} \mathrm{~s}^{-1}$, the speed was increased at 2min intervals to 6, 8 and $10 \mathrm{~m} \mathrm{~s}^{-1}$. The blood samples were collected $15 \mathrm{~s}$ before the end of each step to determine the concentration of lactate, packed cell volume, hemoglobin and red cell values. The results demonstrated a significant increase $(P<0.05)$ in V4 in the groups that received creatine supplementation for 60 days or more when compared to the animals without creatine supplememntation. The other hematological variables were similar to all groups. The results showed that the prolonged creatine supplementation may have a beneficial al effect on the equine athletic performance.
\end{abstract}

Key words: equine, creatine, lactate, hematology, athletic performance.

\section{RESUMO}

O objetivo do presente estudo foi investigar os efeitos da suplementação oral com creatina sobre respostas fisiológicas ao treinamento aeróbico. Doze cavalos da raça
Puro Sangue Árabe foram submetidos a treinamento aeróbico por 90 dias, com ou sem suplementação com creatina, que consistia da administração diária de $75 \mathrm{~g}$ de monoidrato de creatina misturada à ração durante os 90 dias de treinamento. O treinamento físico foi conduzido exclusivamente em esteira rolante de alto desempenho sendo a intensidade do treinamento estabelecida em $80 \%$ da velocidade obtida através da V4 (velocidade na qual a concentração sangüínea de lactato atinge

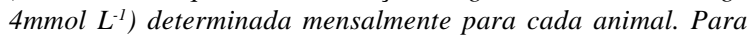
o estabelecimento da $V_{4}$ individual foi empregado um teste físico de esforço crescente em que, após um período de aquecimento de $4 \mathrm{~min}$ a $4 \mathrm{~m} \mathrm{~s}^{-1}$, a velocidade era aumentada à cada intervalo de dois minutos, para 6, 8 e $10 \mathrm{~m} \mathrm{~s}^{-1}$. As amostras sangüíneas foram coletadas $15 \mathrm{~s}$ antes do témino de cada intervalo para a determinação do lactato, hematócrito, hemoglobina e eritrócitos. Os resultados demonstraram um aumento significativo $(P<0,05)$ da $V 4$ dos animais que receberam creatina por 60 e 90 dias quando comparados, no mesmo período, com os animais que não receberam a suplementação. As outras variáveis hematológicas não apresentaram alterações. É possível sugerir que a suplementação prolongada com creatina pode promover efeitos benéficos no desempenho atlético de eqüinos.

Palavras - chave: eqüinos, creatina, lactato, hematologia, desempenho atlético.

\section{INTRODUCTION}

In the last years various ergogenic supplements have been used for improvement of the equine athletic potential, such as creatine. The

${ }^{1}$ Departamento de Morfologia e Fisiologia Animal, Faculdade de Ciências Agrárias e Veterinárias, Campus Jaboticabal, Jaboticabal, SP, Brasil.

${ }^{2}$ Departamento de Cirurgia e Clínica Animal, Faculdade de Ciências Agrárias e Veterinárias, Campus Jaboticabal, Jaboticabal, SP, Brasil.

${ }^{3}$ Departamento de Morfologia e Fisiologia Animal, Faculdade de Ciências Agrárias e Veterinárias, Campus Jaboticabal, Via de Acesso Prof. Paulo D. Castellane s/n, 14884-900, Jaboticabal, SP, Brasil. E-mail: aqueiroz@fcav.unesp.br. Corresponding author. 
phosphorilated form of this substance (creatine phosphate, $\mathrm{CP}$ ) provides energy for muscle contraction in a way similar to that from adenosine triphosphate (ATP), producing a large amount of free energy when the linkage between the molecules of creatine and phosphate is ruptured (SCHUBACK et al., 2000). This substance is a naturally occurring compound that is synthesized endogenously and is stored in abundance in skeletal muscle and plays a pivotal role in maintaining a high adenosine triphosphate/adenosine diphosphate ratio during intense contraction (GREENHAFF, 1997).

The integration of aerobic and anaerobic pathways of energy production is complex. Immediately after the beginning of the exercise, the reserves of $\mathrm{O}_{2}$ in hemoglobin and myoglobin, and also the stores of ATP and CP are utilized. If sufficient $\mathrm{O}_{2}$ is available, it reoxidize most of $\mathrm{NADH}_{2}$ produced, and energy production can continue mainly via aerobic pathways, but if the energy demand increases, there will be a persistent decline in the ATP/ADP ratio, providing a continued stimulus for the glycolytic anaerobic pathway, with a corresponding increase in $\mathrm{NADH}_{2}$, pyruvate and lactate.

Some studies in human beings showed that the monohydrated creatine supplementation may improve the athletic performance in high intensity and low duration exercises (BIRCH et al., 1994; Dentkowski et al., 1997). It has been demonstrated that supplementation with creatine for a prolonged time stimulates muscular hypertrophy during highresistance training (VANDENBERGHE et al., 1997), and increases body weight in human athletes (BALSON et al., 1995). On the other hand, in a recent study (D’ANGELIS et al., 2005) the authors did not find any beneficial effect from prolonged creatine supplementation on the skeletal muscle fiber composition in horses.

At the present time, it is still not clear whether creatine exerts any beneficial effects in horses submitted to aerobic training. Thus, the goal of the present study was to examine the effects of prolonged supplementation with creatine for 90 days on physiological parameters that could reflect the aerobic capacity of horses, such as the blood lactate threshold, red cell count (RBC), packed cell volume (PCV) and hemoglobin $(\mathrm{Hb})$.

\section{MATERIALS AND METHODS}

Twelve Purebred Arabian horses were utilized, both males (5) and females (7), with an initial body weight of $391.0 \pm 25.4 \mathrm{~kg}$ (mean ( SD) and mean age of $8.6 \pm 3.3$ years old. The animals selected for study were evaluated by clinical examination and laboratory tests such as complete blood count and blood biochemistry. They had no signs or symptoms compatible with skeletal muscle lesions, and were monthly delouseda and dewormedb.

The 12 horses were kept in a paddock for a period of eight months of inactivity and then were randomly divided into two groups that were subjected to aerobic training for 90 days, but only one group $\left(\mathrm{CR}_{0}\right)$ received $75 \mathrm{~g}$ creatine monohydratec per animal per day for 90 days $\left(\mathrm{CR}_{30}, \mathrm{CR}_{60}\right.$ and $\left.\mathrm{CR}_{90}\right)$ while the other group served as control group $\left(\mathrm{C}_{0}, \mathrm{C}_{30}, \mathrm{C}_{60}\right.$ and $\mathrm{C}_{90}$ ) and received no supplementation. The animals were kept in a paddock of Brachiaria sp. grass with water ad libitum and receiving supplementation with Cynodon sp. hay and mineralized salt. Creatine was given individually in the stall, and mixed with half of the daily commercial rationd followed by the rest of the meal to make it sure that all the creatine was ingested by the horse.

To determine the daily amount of commercial ration fed, the animals were evaluated monthly for body weight and body score utilizing the protocol recommended by HENNEKE et al. (1983).

Physical conditioning of each animal was performed in a climatized room which contained a high performance treadmille. Before initiation of the training program, the horses were submitted to a 30 days adaptation to handling period. The training program was conducted exclusively on the treadmill according to EVANS (2000). The intensity (velocity) of the training was set at $80 \%$ of $\mathrm{V}_{4}$ (velocity at which the blood lactate concentration reached $4 \mathrm{mmol} \mathrm{L}^{-1}$ ) calculated in a ergometric test. At the end of each training period (30 days), a new exercise test was conducted to establish a new $\mathrm{V}_{4}$. The training velocity was thereby determined monthly for each animal.

The frequency of training consisted of exercises three times a week (alternate days). In the first month of training, each animal exercised for $10 \mathrm{~km}$ 
in a mean time of $50 \mathrm{~min}$. In the second month, the distance run in each exercise was increased to $15 \mathrm{~km}$ with a mean duration of $60 \mathrm{~min}$. In the last month, all the horses exercised $20 \mathrm{~km}$ per session, with a mean duration of $80 \mathrm{~min}$. In addition, a speed play type of training, which encompasses sudden, rapid, relatively short bursts of speed interspersed throughout the exercise bout, was instituted once a week with the aim of stimulating tissues not addressed by slower exercise and increasing the horse's metabolic capacity. This protocol was adopted since some authors (RIDGWAY, 1994; EVANS, 2000) recommended strenuous training sessions as part of the endurance training to develop fitness for fast exercise.

After a warm-up period of 4 minutes at 4.0 $\mathrm{m} . \mathrm{s}^{-1}$, the treadmill was inclinated at $10 \%$ and the speed was gradually increased at 2 minute intervals to 6.0, 8.0 and $10.0 \mathrm{~m} \mathrm{~s}^{-1}$. The blood samples were collected $15 \mathrm{~s}$ before the end of each step by means of an intravenous catheter fixed in the left jugular vein.

After each blood sampling, the whole system was washed out with $2.5 \%$ heparine solution. For this reason, $2.0 \mathrm{ml}$ of blood were discharged at the beginning of each collection. The samples were immediately analyzed for lactate concentration by a portable digital lactimeterf. The individual $\mathrm{V}_{4}$ was determined graphically using an exponential regression.

The PCV was determined by the microhematocrit method (GOLDENFARB et al., 1971) and the hemoglobin level was determined by the hemoglin cyanet colorymetric method (HICN)g. The red cell count was done with a automated counterh.

The results were submmited to the ANOVA considering training split in periods of training. The means were compared by Tukey's test at $\mathrm{P}<0.05$.

\section{RESULTS AND DISCUSSION}

Figure 1 shows that only after 60 and 90 days of training associated to creatine supplementation the $\mathrm{V}_{4}$ increased significantly $(\mathrm{P}=0.0009)$ when compared to the untrained group (day 0 ).

One of the effects of training is the increase of the exercise intensity in which lactate starts to accumulate in the blood stream (COUROUCE, 1998). However, in this study, it could be observed only in

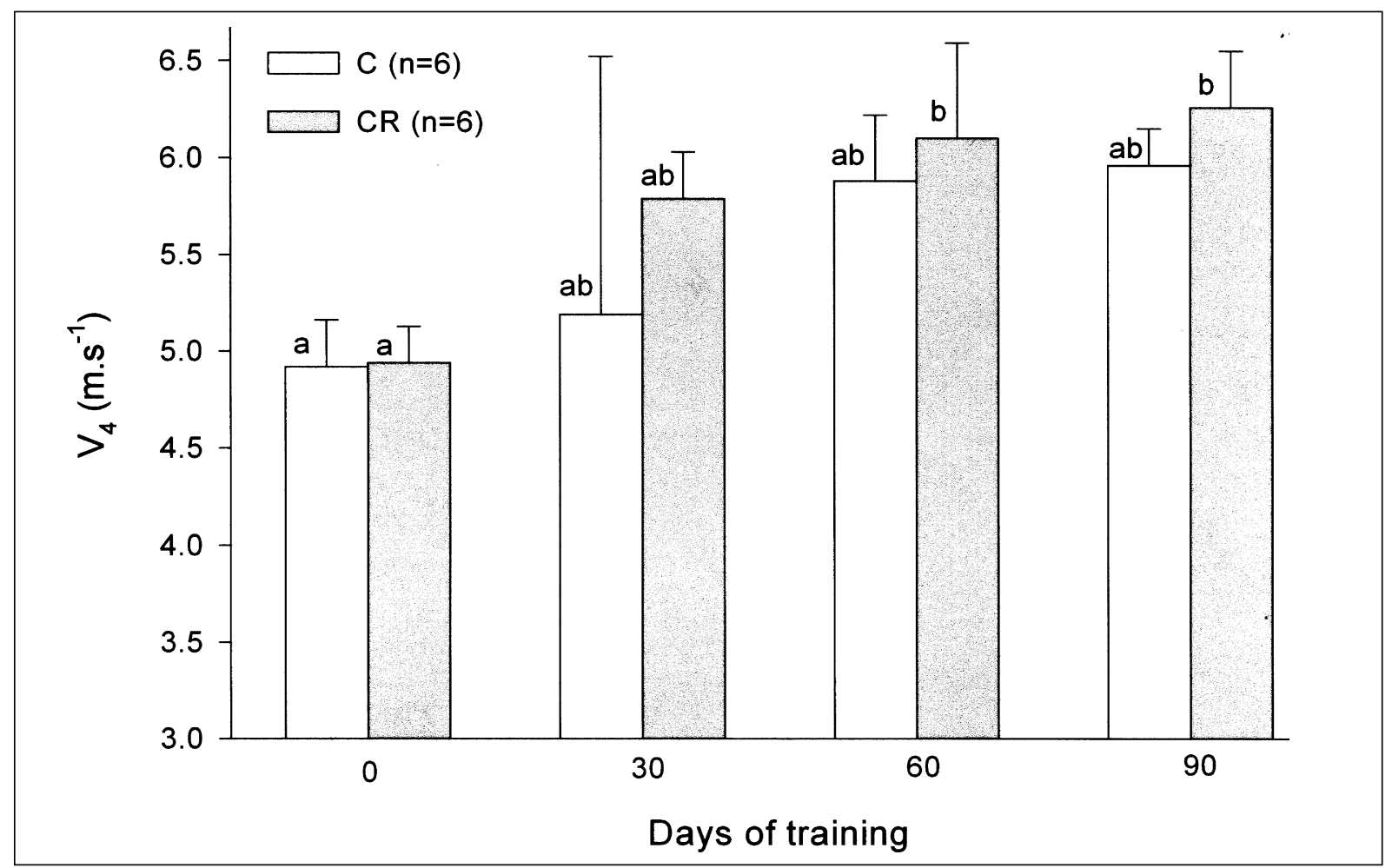

Figure 1 - Change in $\mathrm{V}_{4}$ of Arabian Horses as a function of conditioning duration associated or not, with 75 g of monohydrate creatine over the four exercise tests. Different letters indicate significant increase in $\mathrm{V}_{4}$ from the untrained (day 0 ) to the Tukey test $(\mathrm{P}<0.05)$. Values are expressed as mean \pm S.E.M. 
animals submitted to 60 or 90 days of training and creatine supplementation. The predict value of $\mathrm{V}_{4}$ of the untrained group was $4.94 \mathrm{~m} / \mathrm{s}$ while in the groups that received creatine and training for 60 and 90 days, the values were 6.10 and $6.26 \mathrm{~m} \mathrm{~s}^{-1}$, respectively. These results are in accordance with those of Kurosawa and colleagues (1998) who studied the $\mathrm{V}_{4}$ of five Thoroughbred trained horses and obtained a mean speed of $7.3 \mathrm{~m} \mathrm{~s}^{-1}$.

TRILK et al., (2002) studied the effects of 6 weeks training on $\mathrm{V}_{4}$ and found an increase of $17 \%$ in this parameter. In the present study the increase in $\mathrm{V}_{4}$ was $26.72 \%$, which may be associated to the longer training period. Besides, the training intensity was higher, which may also be associated to the $\mathrm{V}_{4}$ variation. The exact mechanism by which creatine improves the exercise performance has not been determined yet. The effect of creatine supplementation is probably due to the increase in the availability of creatine phosphate, especially on fast contracting muscle fibers, maintaining ATP resynthesis during exercise (GREENHAFF, 1997). This is supported by reports of reduced ammonia and hipoxantines storages during maximum intensity exercises after creatine intake. These plasmatic metabolites are in higher concentrations when the ATP resynthesis is interrupted (GREENHAFF et al., 1993).

The data related to long-term creatine supplementation are scarce. In spite of that, GREENHAFF (1997) stated that in long run, creatine may allow athletes to benefit from being able to train without fadigue at an intensity higher than that to which they are normally trained. For this reasons, creatine supplementation could be viewed as a significant development in sports-related nutrition.

Another evidence on the possible benefits that creatine supplementation could bring, is related by OP'T EIJNDE et al. (2001) who concluded that shortterm high dose creatine feeding enhances glycogen storage in rat skeletal muscle. Recently, similar results were obtained in men by VAN LOON et al. (2004). Indeed, this effect could be useful for Arabian horses competing in long duration and sub-maximum intensity tests.

Otherwise, no influence was observed in muscle metabolic responses, nor in the concentration of creatine in plasma or in the transport of creatine in muscle of horses after a daily intake of $50 \mathrm{~g}$ of creatine monohydrate for 7 days (SCHUBACK et al., 2000). Similar results were described by KINUGASA et al. (2004) who found no influence of the short term creatine supplementation on short duration repetitive sprint performance and muscle metabolic state during sprint cycling evaluated in humans. These findings disagreed with those of this study which can be explained by the higher dose and longer supplementation period.

The packed cell volume, the red blood cells and the hemoglobin content did not show significant statistical difference between the groups trained for 90 days with or without creatine supplementation (Figure 2) and also no evidence of any difference that could be attributed to the training by itself (data not shown). Although, there was a clear increasing tendency of all values, related to the intensity of the effort during the exercise tests.

These results are in accordance with Rose and HODGSON (1982) and ROSE et al., (1983) who found no changes in the hematological parameters of horses submitted to routine training for endurance competitions. Additionally, the endurance horse often present low concentration of blood components (ROSE \& ALLEN, 1985) which may be associated to the increase in plasmatic volume due to the training process (MCKEEVER et al., 1987). In contrary, in thoroughbred horses training causes a moderate increase in the packed cell volume, hemoglobin concentration and red blood cell count (ALLEN \& POWELL, 1983).

In the present study, the behavior of the blood component concentration that occurred along the steps of the exercise test may be explained by the effort-dependent splenic emptying (PERSSON \& BERGSTEN, 1995) associated to the occurrence of fluid losses during the exercise.

\section{CONCLUSIONS}

The horses that received prolonged oral creatine supplementation associated to the training showed an improved athletic performance, as suggested by the delayed lactate accumulation.

\section{ACKNOWLEDGEMENTS}

Research supported by the Fundação de Amparo à Pesquisa do Estado de São Paulo - FAPESP, Proc. 01/02207-4. 


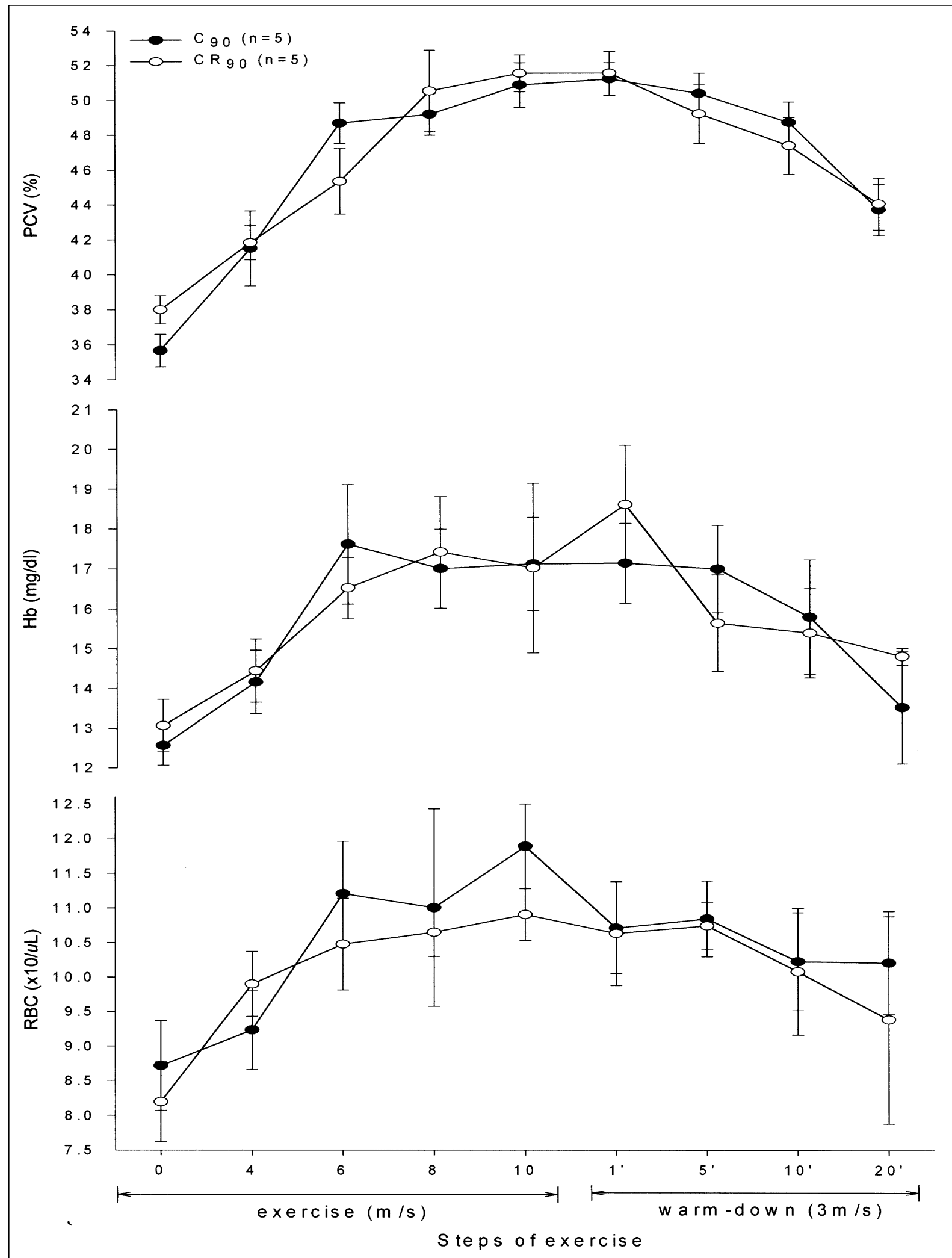

Figure 2 - Changes in haematology (mean \pm SEM) associated with treadmill exercise in five trained horses for ninety days $\left(\mathrm{C}_{90}\right)$ and five trained for ninety days plus $75 \mathrm{~g}$ monohydrate creatine $\left(\mathrm{CR}_{90}\right)$ all Arabian horses. $\mathrm{RBC}$ - red cell count; $\mathrm{Hb}-$ haemoglobin; PCV - Packed cell volume. 


\section{SOURCES AND MANUFACTURES}

a- Butox - Hoechst Roussel Vet. S.A. - Rio de Janeiro, RJ, Brazil

b- Ivotan Plus Pasta - Hoechst Roussel Vet. S.A. - Rio de Janeiro, RJ, Brazil

c- Vetnil, Louveira, SP, Brazi

d- Nutriage Mix - Guabi - Campinas, SP, Brazil

e- Esteira Galloper 5500 - Sahinco LTDA - São Paulo, SP, Brazil

f- Accusport - Boering Mannheim - Castle Hill, Australia

g- Labtest Kit, Lagoa Santa, MG, Brazil

h- CELM, Barueri, SP, Brazil

The present work agrees to the "Ethical Principles in Animal Experimentation" adopted by the "Brazilian College of Animal Experimentation" and was approved by the University's Institutional Animal Care and Use Committee.

\section{REFERENCES}

ALLEN, B.V.; POWELL, D.G. Effects of training and time of day of blood sampling on the variation of some common hematological parameters in normal Thoroughbred racehorses. In: SNOW, D.H. et al. Equine exercise physiology. Cambridge: Granta, 1983. p.328.

BALSOM. P.D. et al. Skeletal muscle metabolism during short duration high-intensity exercise: influence of creatine supplementation. Acta Physiol Scand, v.154, n.3, p.303310, 1995.

BIRCH, R. et al. The influence of dietary creatine supplementation on performance during repeated bouts of maximal isokinetic cycling in man. Eur J Appl Physiol, v.69, p.268-270, 1994

COUROUCÉ, A. Endurance and sprint training. In: CONFERENCE OF EQUINE SPORTS MEDICINE SCIENCE, 1998, Cordoba. Proceedings... Cordoba: CESMAS, 1998. p. 203-218.

D’ANGELIS, F.H.F. et al. Aerobic training, but not creatine supplementation, alters the gluteus medius muscle. J Anim Sci, v.83, p.579-585, 2005.

DENTKOWSKI, A. et al. Effect of creatine supplementation on the performance in supramaximal intermittent exercise. Biol Sport, v.14, p.290-298, 1997.

EVANS, D.L. 2000. Training and fitness in athletic horses: rural industries research and development corporation. Accessed Jun. 21, 2001. Online. Available: http:// www.rirdc.gov.au/reports/Index.htm.

GOLDENFARB, P.B. et al. Reproducibility in the hematology laboratory: the microhematocrit determination. Am J Clinical Pathol, v.56, p.35-39, 1971.

GREENHAFF, P.L. et al. Influence of oral creatine supplementation of muscle torque during repeated bouts of maximal voluntary exercise in man. Clin Sci Sports, v.84, p.565-571, 1993.
GREENHAFF, P.L. The nutritional biochemistry of creatine. Nutr Biochem, v.8, p.610-618, 1997

HENNEKE, D.R. et al. Relationship between condition score, physical measurements and body fat percentage in mares. Equine Vet J, v.15, p.371-372, 1983

KINUGASA, R. et al. Short-term creatine supplementation does not improve muscle activation or sprint performance in humans. Eur J Appl Physiol, v.91, p.230-237, 2004.

KUROSAWA, M. et al. Effects of caffeine on performance, cardiorespiratory function and plasma hormonal responses during exhaustive treadmill exercise in the thoroughbred horse. J Equine Sci, v.9, n.2, p.33-43, 1998

MCKEEVER, K.H. et al. Exercise training-induced hypervolemia in the horse. Med Sci Sports Exercise, v.19, p.21, 1987.

OP 'T EIJNDE, B. et al. Effect of creatine supplementation on creatine and glycogen content in rat skeletal muscle. Acta Physiol Scand, v.171, n.2, p.169-176, 2001.

PERSSON, S.G.B.; BERGSTEN G. Circulatory effects of splenectomy in the horse: effect on blood flow and blood lactate at rest and during exercise. Zentralbl Vet Med, v.A20, p.801, 1995.

RIDGWAY, K.J. Training endurance horses. In: HODGSON, D.R; ROSE, R.J. The athletic horse. Philadelphia: Saunders, 1994. p.409-417.

ROSE, D.J.; HODGSON D.R. Hematological and biochemical parameters in endurance horses during training. Equine Vet $\mathbf{J}$, v.14, p.144, 1982

ROSE R.J.; ALLEN, J.R. Hematologic responses to exercise and training. Vet Clinical North Am: Equine Pract, v.1, p.461, 1985

SCHUBACK, K. et al. Effect of creatine supplementation on muscle metabolic response to a maximal treadmill exercise test in Standardbred horses. Equine Vet J, v.32, n.6, p.533-540, 2000.

TRILK, J.L. et al. A lactate-guided conditioning program to improve endurance performance. Equine Vet J, Suppl. v.34, p.122-125, 2002.

VANDENBERGHE, K. et al. Long term creatine intake is beneficial to muscle performance during resistance training. $\mathbf{J}$ Appl Physiol, v.83, p.2055-2063, 1997.

VAN LOON, L.J.C. et al. Creatine supplementation increases glycogen storage but not GLUT-4 expression in human skeletal muscle. Clin Sci, v.106, p.99-106, 2004.

ROSE, R.J. et al. Responses to submaximal treadmill exercise and training in the horse: Changes in haematology, arterial blood gas and acid base measurements, plasma biochemical values and heart rate. Vet Rec, v.113, p.612-618, 1983. 